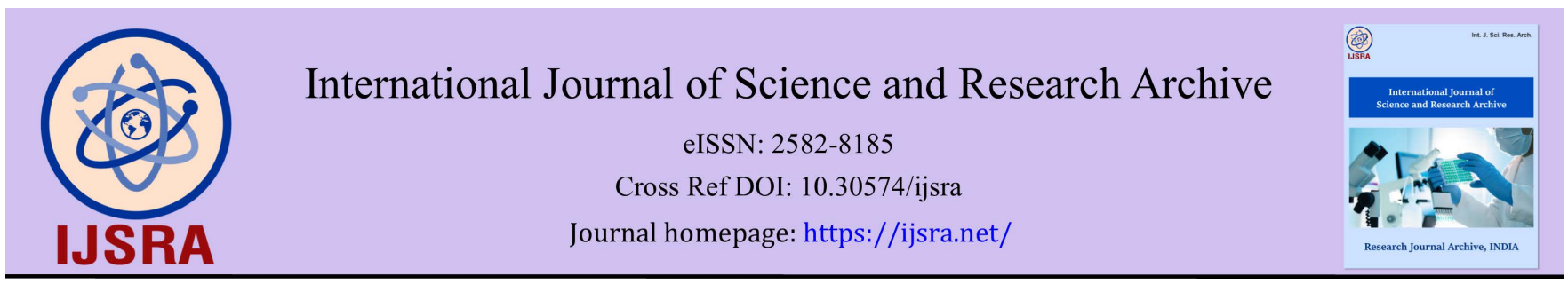

(RESEARCH ARTiClE)

\title{
Relations between biomass of (Smilax scobinicaulis) Fresh Roots and Daily Solar Radiation
}

\author{
Bing-Hua Liao 1, 2, \\ 1 The Key Laboratory of Ecological Restoration in Hilly Areas, Forestry Department of Henan Province, Institute of \\ chemistry and environmental engineering, Ping-ding-shan University, Ping-ding-shan City, 467000, China. \\ 2 Institute of life and science, Henan University, Kai-feng City, He-nan Province, 475004, China.
}

International Journal of Science and Research Archive, 2021, 04(01), 018-025

Publication history: Received on 25 September 2021; revised on 07 November 2021; accepted on 09 November 2021

Article DOI: https://doi.org/10.30574/ijsra.2021.4.1.0161

\begin{abstract}
(Smilax scobinicaulis) not only is a medicinal material plant by treating joint pain, but also it is a widely distributed wide species from $500 \mathrm{~m}$ to $3100 \mathrm{~m}$ in Mei County of China. However, explaining links between total biomass of fresh roots and daily solar radiation is difficult. Herein explains that it is an increasing of total biomass of fresh roots with increasing of daily solar radiation, a link between total biomass of fresh roots and daily solar radiation is a significant positive correlation from $20.578 \mathrm{~mol} / \mathrm{m}^{2} \bullet \mathrm{d}$ to $24.158 \mathrm{~mol} / \mathrm{m}^{2} \bullet \mathrm{d}$ along elevation from $500 \mathrm{~m}$ to $1500 \mathrm{~m}(P<0.01)$; it is a decreasing of this total biomass of fresh roots with increasing of daily solar radiation, it is a link between this total biomass of fresh roots and daily solar radiation is the significant negative correlation from $24.15 \mathrm{~mol} / \mathrm{m}^{2} \bullet \mathrm{d}$ to $27.246 \mathrm{~mol} / \mathrm{m}^{2} \bullet \mathrm{d}$ along elevation from $1500 \mathrm{~m}$ to $3100 \mathrm{~m}(P<0.01)$. Herein provides key areas ecological adaptation of daily solar radiation and six landscapes. So, this has key theoretical and practical significance by medicinal species protection for future of human well-being at daily solar radiation at spatial-temporal-environmental-disturbance scales (STEDS).
\end{abstract}

Keywords: Total biomass of fresh roots; Daily solar radiation; Links; Medicinal; Areas ecological adaptation

\section{Introduction}

More and more scientists have assessed the links between total biomass of fresh roots of medical plants and environments along elevation from total biomass of fresh roots (plant functional groups, biodiversity, height, total biomass of fresh roots) of medicinal species perspective by biodiversity researches (Table 1) ${ }^{1-21}$, which based on better future of human heath by the finding medicinal plants. However, traditional medicinal plant species with typical history spanning over 1500 years, as well as areas ecological adaptation of a lot of total biomass of fresh roots of plant are unknown and values of medicinal species also cannot be utilized along eco-landscape environmental gradient ${ }^{12-21}$.

(Smilax scobinicaulis) not only is a vital medicinal material plant of treating joint pain, but also it is widely distributed wide specie along elevation from 500 to $3100 \mathrm{~m}$ by "big data" of our long-time investigation in Mei County. The species is belonging to Smilax L. genus of Liliaceae families of Monocotyledoneae in Angiospermae. However, understanding the links between total biomass of fresh roots of medical plants and dynamics of daily solar radiation along elevation is unknown, as well as the linkages between total biomass of fresh roots of plants and daily solar radiation is difficult finding along elevation and environmental factors ${ }^{11-27}$. And, elevation and environmental (daily solar radiation, disturbances) gradient also influence on total biomass of fresh roots (biomass, biodiversity, structure, et al.) of plant species in "big data" investigation of our long years researches Understanding these medical values of medicinal spices

\footnotetext{
${ }^{*}$ Corresponding author: Bing-Hua Liao

The Key Laboratory of Ecological Restoration in Hilly Areas, Forestry Department of Henan Province, Institute of chemistry and environmental engineering, Ping-ding-shan University, Ping-ding-shan City, 467000, China.
} 
and links between total biomass of fresh roots of medicinal plant species and the daily solar radiation and different areas ecological adaptation of medical plants is a vital rule along different environments.

As such, there is not only the vital links between total biomass of fresh roots of species and daily solar radiation, but also there is a series of (good, better, best) this species areas ecological adaptation of daily solar radiation in six nearnatural ecosystems for better future of ecosystems.

Table 1 Evaluation of links between dynamics of medicinal plants and environmental factors

\begin{tabular}{|c|c|}
\hline Assessments of links between multilevel medicinal plant and elevation & Authors \\
\hline Links between biodiversity of plant functional groups and elevation at STEDS. & Liao, et al., $2010{ }^{1}$. \\
\hline Links between biomass of medicinal herbs and elevation in wetland landscape. & Liao, et al., $2011 \mathrm{a}^{2}$. \\
\hline Links between plant functional groups diversity and elevation in forest. & Liao, et al., $2011 \mathrm{~b}^{3}$. \\
\hline Links between plant functional groups and elevation in near-natural forests. & Liao, et al., $2014 \mathrm{a}^{4}$. \\
\hline Links between number of medicinal tree species and elevation in forestation. & Liao, et al., 2019 a ${ }^{5}$. \\
\hline Links between average height of medicinal tree and elevation in landscapes. & Liao, et al., 2019 b 6 . \\
\hline Links between medicinal tree trunk volume and elevation in forests. & Liao, et al., 2019 c ${ }^{7}$. \\
\hline Links between number of tree community crown volume and elevation. & Liao, et al., $2019 \mathrm{~d}^{8}$. \\
\hline Links between number of individual specie's crown volumes and elevation. & Liao, et al., $2019 \mathrm{e}^{9}$ \\
\hline Links between plant diversity and different disturbance of different elevation. & Liao, 2014 b ${ }^{10}$. \\
\hline Links between dry weight biomass of biomedical plant and elevations. & Liao, 2020 a ${ }^{11}$. \\
\hline Links between total biomass of fresh weight of medical plant and elevations. & Liao, 2020 b ${ }^{12}$. \\
\hline Links between vegetation coverage of biomedical plant and elevation. & Liao, 2020 c ${ }^{13}$ \\
\hline Links between pair's co-dominance abundance dominancy and elevation. & Liao, $2020 \mathrm{~d}^{14}$ \\
\hline Relation between plant average height of biomedical plant and elevation. & Liao, 2020 e ${ }^{15}$ \\
\hline Links between biomass of biomedical plant roots cuticle and elevation. & Liao, $2020 \mathrm{f} 16$ \\
\hline Links between biomass of medical plant roots cuticle and daily solar radiation. & Liao, $2020 \mathrm{~g}^{17}$. \\
\hline Links between leafstalk biomass of biomedical plant and elevation. & Liao, $2020 \mathrm{~h}^{18}$. \\
\hline Links between biomass of biomedical plant stems cuticle and elevation. & Liao, 2020 i 19. \\
\hline Links between Important Values of biomedical plant species and elevations & Liao, $2020 \mathrm{j}^{20}$. \\
\hline Links between moisture content of biomass of biomedical plant an & Liao, $2020 \mathrm{k}^{21}$. \\
\hline
\end{tabular}

\section{Material and methods}

The typical area is local in three vegetation zones in China: firstly, evergreen vegetation in north subtropical zone; secondly, evergreen and deciduous coniferous and broad-leaved mixed forest in north subtropical and warm temperate transition; thirdly, deciduous vegetation in warm temperate zone by large total biomass of fresh roots investigation of medicinal plant. Thus, our research area is local in evergreen and deciduous coniferous and broad-leaved mixed forest in north subtropical and warm temperate transition (landscape types included: urban, rural settlement, wetland, forest, grassland, farmland, river landscape as well as mixed zone landscape interaction each other) along elevation and environmental gradient in Mei County of Shan'xi Province of China (Figure 1).

There is a long time investigation by the links between medicinal plant species diversity and environments from 2005 to 2019. Investigation of "big data" included that the dynamics of total biomass of fresh roots of key medicinal plants or other index along environmental gradients (Fu-niu Mountain, Yellow River, Ye County, Yi-luo River, Mei-county, Bai-gui Lake, et al.) ${ }^{2-25}$. 


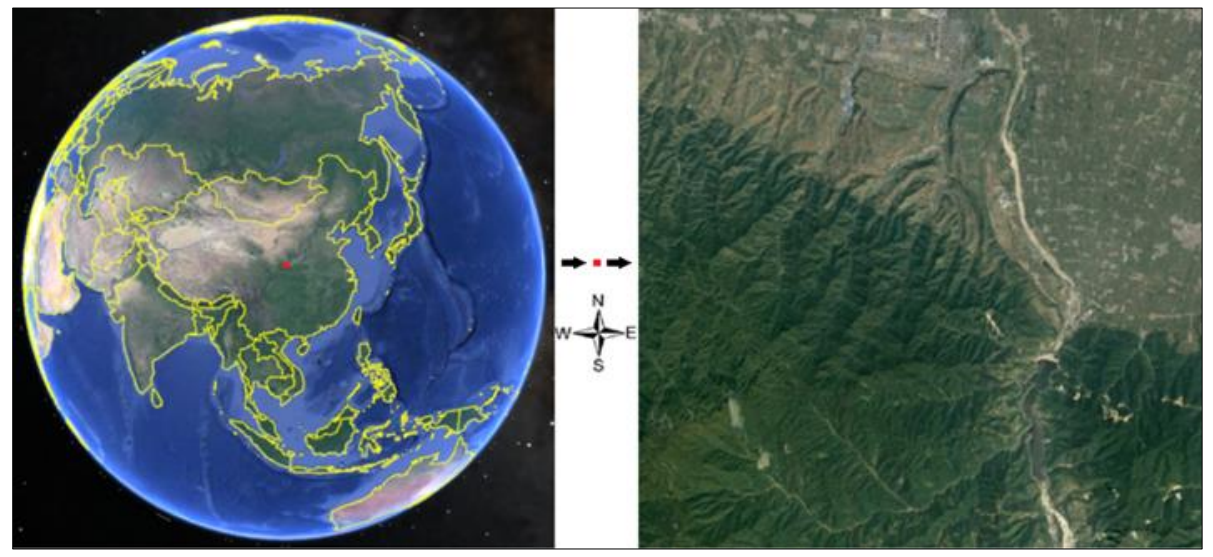

Figure 1 A Digital Cadaster Map and Typical Location in Mei County of China of Earth

Thus, there is the links between total biomass of (Smilax scobinicaulis) fresh roots and daily solar radiation, and there is a series of (good, better, best) natural landscapes areas ecological adaptation of daily solar radiation of this medical plant species by the "big data" of the ecological investigation, qualitative analysis, quantitative statistics for predicting on ecological rules ${ }^{3-31}$.

\section{Results}

(Smilax scobinicaulis) not only is a vital medicinal material plant of treating joint pain, but also it is widely distributed wide plant species along elevation from 500 to $3100 \mathrm{~m}$ in natural ecosystems along elevation from $500 \mathrm{~m}$ to $3100 \mathrm{~m}$ in Mei County. However, understanding daily solar radiation effect on the links between this total biomass of fresh roots and daily solar radiation is difficult. Using "big data" investigation, this research showed there are three rules at increasing of daily solar radiation and elevation gradient in Mei County of Shan'xi Province of China:

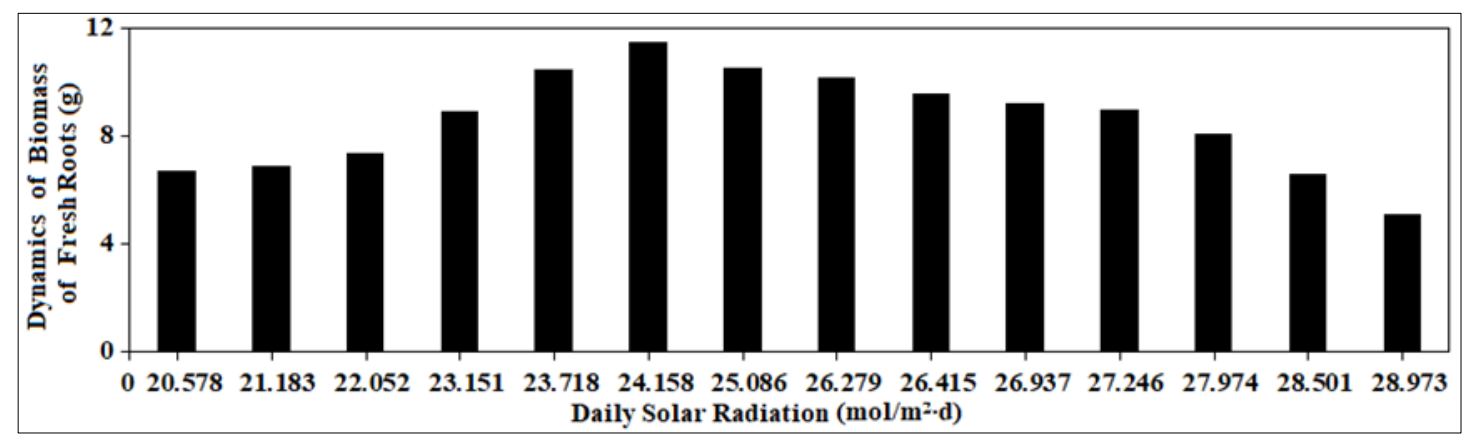

Figure 2 Dynamics of Total Biomass of Fresh Roots along Daily Solar Radiation Gradient

Firstly, this research proposed that not only there is the increasing of total biomass of fresh roots of this plant species with the increasing daily solar radiation, and there is the significant positive correlation between total biomass of fresh roots of this species and daily solar radiation from $20.578 \mathrm{~mol} / \mathrm{m}^{2} \bullet \mathrm{d}$ to $24.158 \mathrm{~mol} / \mathrm{m}^{2} \bullet \mathrm{d}(P<0.01)$ along elevation from $500 \mathrm{~m}$ to $1500 \mathrm{~m}$, but also there is the decreasing of total biomass of fresh roots of this plant species with the increasing of daily solar radiation, and there is the significant negative correlation between total biomass of fresh roots of this plant species and daily solar radiation from $24.158 \mathrm{~mol} / \mathrm{m}^{2} \bullet \mathrm{d}$ to $28.973 \mathrm{~mol} / \mathrm{m}^{2} \bullet \mathrm{d}(P<0.01)$ along elevation from $1500 \mathrm{~m}$ to $3100 \mathrm{~m}$. Because there is the increasing of daily solar radiation with increasing daily solar radiation and elevation is the significant positive correlation along elevation gradient from $500 \mathrm{~m}$ to $3100 \mathrm{~m}(P<0.01)$ at STEDS (Figure 2, 3; Table 2, 3).

Secondly, this research provided good areas ecological adaptation of daily solar radiation of this medical plant species is local in the areas ecological adaptation of daily solar radiation from $20.578 \mathrm{~mol} / \mathrm{m}^{2} \bullet \mathrm{d}$ to $28.973 \mathrm{~mol} / \mathrm{m}^{2} \bullet \mathrm{d}$ along elevation from $500 \mathrm{~m}$ to $3100 \mathrm{~m}$, and not only there are better areas ecological adaptation of daily solar radiation of this species from $23.151 \mathrm{~mol} / \mathrm{m}^{2} \bullet \mathrm{d}$ to $27.974 \mathrm{~mol} / \mathrm{m}^{2} \bullet \mathrm{d}$ along elevation gradient from $1100 \mathrm{~m}$ to $2700 \mathrm{~m}$, but also there are the best areas ecological adaptation of daily solar radiation of this medical plant species from $23.718 \mathrm{~mol} / \mathrm{m}^{2} \bullet \mathrm{d}$ to $25.086 \mathrm{~mol} / \mathrm{m}^{2} \bullet \mathrm{d}$ along elevation from $1300 \mathrm{~m}$ to $1700 \mathrm{~m}$ at STEDS in Mei County (Figure 2,3). 


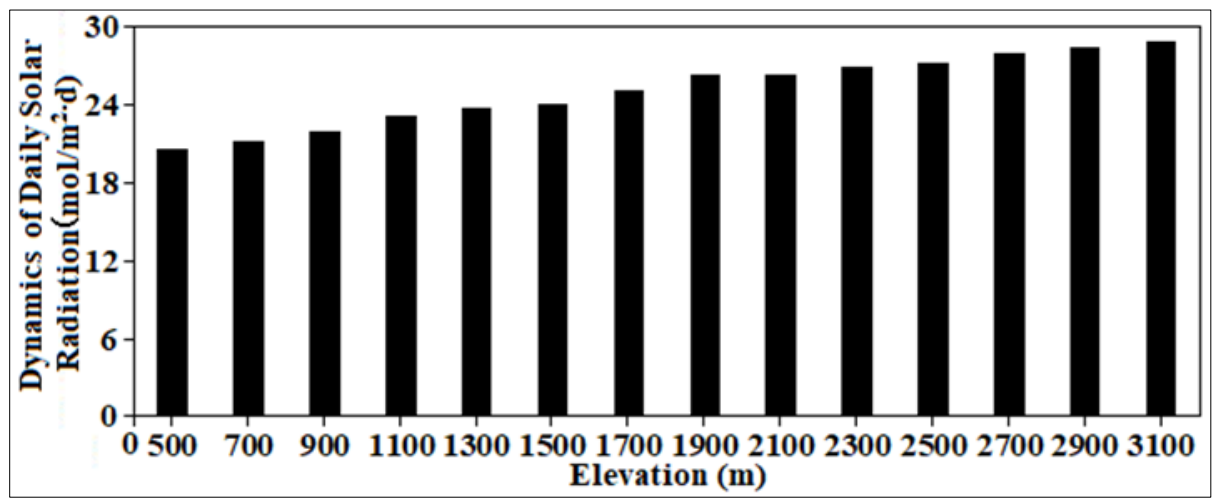

Figure 3 Dynamics of Daily Solar Radiation along Elevation Gradient

Table 2 Correlations between Total Biomass of Fresh Roots and Daily Solar Radiation

\begin{tabular}{|l|c|}
\hline Daily Solar Radiation along Elevation Gradient & Plant Biomass of Fresh Roots \\
\hline Daily Solar Radiation From $500 \mathrm{~m}$ to $1500 \mathrm{~m}$ & $0.958^{* *}$ \\
\hline Daily Solar Radiation From $150 \mathrm{~m}$ to $3100 \mathrm{~m}$ & $-0.946^{* *}$ \\
\hline \multicolumn{2}{|c|}{ Note: ${ }^{* *}, P<0.01}$.
\end{tabular}

Thirdly, this research suggested that medicinal plant (Smilax scobinicaulis) of treating joint pain is local in six natural landscape types (forest, mixed between grassland and forest, mixed between forest and wetland, mixed between forest and river, mixed between forest and urban, mixed between forest and rural settlement), because of there is result of dynamics of air and soil environments along elevation and environmental gradient at "big data" STEDS (Figure 1).

Table 3 Correlations between Total Biomass of Fresh Roots Daily Solar Radiation Gradient

\begin{tabular}{|c|c|}
\hline Elevation (m) & Elevation Gradient from 500m to 3100m \\
\hline Daily Solar Radiation & $0.992^{* *}$ \\
\hline
\end{tabular}

Thus, this research finds a series of typical (good, better, best) areas ecological adaptation of (Cremastra appendiculata) of treating joint pain along elevation (daily solar radiation), and there is a linkage between total biomass of fresh roots and daily solar radiation along elevation gradient.

\section{Discussion}

Predicting dynamics of total biomass of fresh roots of medicinal species is very difficult ${ }^{2-35}$. This research suggested three rules with biomass of fresh roots of this species:

Firstly, it is a significant positive correlation between the total biomass of fresh roots of this species and daily solar radiation along elevation from $500 \mathrm{~m}$ to $1500 \mathrm{~m}(P<0.01)$, because of it is an increasing of total biomass of fresh roots with increasing of daily solar radiation from $20.578 \mathrm{~mol} / \mathrm{m}^{2} \bullet \mathrm{d}$ to $24.158 \mathrm{~mol} / \mathrm{m}^{2} \bullet \mathrm{d}$. Ant, it is a significant negative correlation between Total biomass of fresh roots and daily solar radiation along elevation from along elevation from $1500 \mathrm{~m}$ to $3100 \mathrm{~m}(P<0.01)$, because of it is a decreasing of total biomass of fresh roots with increasing of daily solar radiation from $24.158 \mathrm{~mol} / \mathrm{m}^{2} \bullet \mathrm{d}$ to $27.246 \mathrm{~mol} / \mathrm{m}^{2} \bullet \mathrm{d}(P<0.01)$ at STEDS in landscapes.

Secondly, this research provided good areas ecological adaptation along elevation from 500 to $3100 \mathrm{~m}$, the better areas ecological adaptation along elevation from 1100 to $2500 \mathrm{~m}$, and the best areas ecological adaptation of daily solar radiation of this medical plant along elevation from 1300 to $1700 \mathrm{~m}$ is local in Mei County of China along environmental gradient at STEDS (Figure 2, 3).

Thirdly, this research suggested that total biomass of fresh roots of this species of treating joint pain is local in six nearlandscape types (forests, mixed landscapes between forestation and wetland, mixed landscapes between grassland and 
forestation, mixed landscapes between forest and urban, mixed landscapes between forest and river, mixed landscapes between forest and rural settlement) by "big data" and researches along other environmental gradients (Figure 1).

As such, this study has a vital theoretical and practical significance for the reasonable protection of total biomass of fresh roots of this species along the daily solar radiation and elevation gradient in six natural landscapes. Because of this plant species not only is a vital widely distributed wide medicinal plant species of treating joint pain, but also there are three rules by the links between total biomass of fresh roots of this species and daily solar radiation. In short, regional planners need regulation a lot of landscape sustainability based on researches on total biomass of fresh roots of medical plant (biodiversity, composition, structure, et al.) by "big data" investigation, qualitative analysis, quantitative statistics, ecological linguistic rules and theory of the links between biodiversity and environments in the global, local, regional landscapes for the better future of human health and ecosystem stability (functions, structures, services) and human health along elevation, daily solar radiation, or other environmental factors in multilevel scale ${ }^{1-15,26-44}$.

\section{Future work}

Indeed, a better regional regulator and local government need a better planning and regulation a lot of medicinal plant management eco-sustainability of ecosystems by the researches on biomass of leafstalk along elevation and environments with dynamics of biodiversity in the global, local, regional natural ecosystem types with the ways "big data" investigation, quantitative statistics, scientific analysis for better future of vital vegetation ecosystems and human well-being $32-43$.

Next work this finding is a basal knowledge for the better understanding the interrelations between environmental factors and multilevel diversity (e.g., landscapes, population, communities, and species level) 44-48. Future human ecological cognitive linguistic theory ${ }^{49}$ must understand the different environmental factors influencing the multilevel species ecological traits (such as leaves, stem barks, roots $^{50}$, resources and genetic breeding ${ }^{51}$, synthetic metabolism ${ }^{52}$, biodiversity 53 , adventitious roots ${ }^{54}$, microbiome shift ${ }^{55}$, anti-infective plants ${ }^{56}$ ) for decrease ecosystem collapse and biodiversity loss ${ }^{57}$ by green chemical approach ${ }^{58}$, phytochemistrym, therapeutics methods ${ }^{59}$.

\section{Conclusion}

Here, herein shows that (Smilax scobinicaulis) not only is a medicinal material plant by treating joint pain, but also it is a widely distributed wide species from $500 \mathrm{~m}$ to $3100 \mathrm{~m}$ in Mei County of China. Herein explains that it is an increasing of total biomass of fresh roots with increasing of daily solar radiation, total biomass of fresh roots and daily solar radiation is a significant positive correlation from $20.578 \mathrm{~mol} / \mathrm{m}^{2} \bullet \mathrm{d}$ to $24.158 \mathrm{~mol} / \mathrm{m}^{2} \bullet d$ from $500 \mathrm{~m}$ to $1500 \mathrm{~m}(P<0.01)$ elevation; it is a decreasing of this total biomass of fresh roots with increasing of daily solar radiation, a link between total biomass of fresh roots and daily solar radiation is a significant negative correlation from $24.15 \mathrm{~mol} / \mathrm{m}^{2} \bullet \mathrm{d}$ to $27.246 \mathrm{~mol} / \mathrm{m}^{2} \bullet \mathrm{d}$ from $1500 \mathrm{~m}$ to $3100 \mathrm{~m}$ elevation $(P<0.01)$. Herein shows key eco-adaptation of daily solar radiation and six landscapes. So, this has key theoretical and practical significance by medicinal species for future of human wellbeing at daily solar radiation.

\section{Compliance with ethical standards}

\section{Acknowledgments}

This work was supported by A Grade of Key Disciplines of Environmental Science Foundation, B Grade of Key Disciplines of Mistrials Science of Ping-Ding-shan University in China; Science and Technology Department of He'nan Province Foundation (KJT-17202310242; 092102110165) ; Subprojects by Intergovernmental Platform on Biodiversity and Ecosystem Services (IPBES); and better ideas of researchers of "1st Biotechnology World Congress" in 2011, "2st Biotechnology World Congress" in 2012, "3st Biotechnology World Congress" in 2013 is appreciated.

\section{References}

[1] Liao BH, Wang XH. Plant functional group classifications and a generalized hierarchical framework of plant functional traits, African Journal of Biotechnology. 2010 Dec; 9(54): 9208-13.

[2] Liao BH, Ding SY, Guo-Fu Liang GF, Guo YL, Tian L, Shu S, Zhang Y, Hu HX. Dynamics of plant functional groups composition along environmental gradients in the typical area of Yi-Luo River watershed. African Journal of Biotechnology. 2011 Oct; 10(65): 14485-92. 
[3] Liao BH, Ding SY, Hu N, Gu YF, Lu XL, Liang GF, Liu J, Fan YL, Zhai YJ, Ding SP, Ding S. Dynamics of environmental gradients on plant functional groups composition on the northern slope of the Fu-Niu Mountain Nature Reserve. African Journal of Biotechnology. 2011 Dec; 10(82): 18939-47.

[4] Liao BH, Liu QF, Lu D, Cao XL, Lei ZL, Si XX, Guo XN, Huang BX, Zhang WW, Wen F, Niu J, Zhu W, Wang RJ, Li JJ, Dong H, Zhang C, Li ZK, Chu HX, Chai JY, Chen ZH, Wang ZC, Li-Sha Ma LS, Qiu BB, Li CP, Hong Y, Yin CC, Qiao XP, Chen JM, Wang SW, Miao HH, Li WL, Meng N, Ye HL, Yang ML, Liu GH, Chen XM, Xu L, Tu CL, Guan YW, Dong JH, Pan WJ, Dong CX, Wang P, Xiao XY, Wang Z, Ma JJ, Ruan HB, Zhang ZZ, Zhang J, Tian YL, Ning Y, Liu Y, Gao YH, Zhou QP, Sheng ZF, Yu HL, Huang BH, Yuan XQ, Cheng Z, Yang MF, Xu Y. Dynamics of environmental gradients on plant functional groups composition species in near-natural community ecological restoration on the southern slope of the Fu-Niu Mountain Nature Reserve. Journal of Science. 2014 Jun; 4(5): 306-12.

[5] Liao BH, Liu M, Huang CZ, Zhang QX, Chang Z, Wang S, Wang XM, Liu QX, Zhang JG, Liu YX. Dynamics of (Sophora japonica) Community's Tree Individual Number along Elevation Gradient in Ye County. International Journal of Pharmacognosy and Pharmaceutical Sciences. 2019 Feb; 1(2): 1-4.

[6] Liao BH, Liu YP, Zuo H, Xu YL, Xia JR, Zhang XG, Jiang CG, Song CJ, Yu ZY. Elevation Dynamics of (Sophora japonica) Community's Height in Ye County. International Journal of Research Pharmaceutical and Nano Sciences. 2019 Feb; 8(1): 48- 54.

[7] Liao BH, Liu YP, Zuo H, Kong YY, Xia JR, Song CJ, Yu ZY, Zhang XG, Jiang CG, Xu YL.. Dynamics of 18 (Sophora japonica) Tree Community's Total Trunk Volume along Elevation Gradient in Ye County. International Journal of Current Advanced Research. 2019 Jun; 8(6): 19063-66.

[8] Liao BH, Liu YP, Zuo H, Xia JR, Yu ZY, Song CJ, Zhang XG, Jiang CG, Xu YL. Dynamics Crown Volume of 18 (Sophora japonica) Tree Communities along Elevation Gradient in Ye County. Open Journal of Ecology. 2019 Jul; 9 (7): 20915.

[9] Liao BH, Liu YP, Zuo H, Xu YL, Xia JR, Zhang XG, Jiang CG, Song CJ, Yu ZY. Dynamics of 18 (Sophora japonica) Tree Individual Specie's Crown Volume along Elevation Gradient in Ye County. International Journal of Research Pharmaceutical and Nano Sciences. 2019 Feb; 8(1): 62-68.

[10] Liao BH. A new model of dynamic of plant diversity in changing farmlands, implications for the management of plant biodiversity along differential environmental gradient in the spring. African Journal of Environmental Science and Technology. 2014 Mar; 8(3): 171- 77.

[11] Liao BH. Links between dry Weight Biomass of (Cremastra Appendiculata) of Biomedical and Pharmaceutical Plant and Elevations by Long-time Investigation of "Big Data". World Journal of Pharmaceutical Research. 2020; 9(Oct): 14-21.

[12] Liao BH. Links between Total Biomass of Fresh Weight of (Cremastra Appendiculata) and Elevation in Biomedical and Pharmaceutical Plant Science by Long-time Investigation of "Big Data". European Journal of Biomedical and Pharmaceutical sciences. 2020 0ct; 7(11): 83-88.

[13] Liao BH. Links between Vegetation Coverage of (Cremastra Appendiculata) and Elevation in Biomedical and Pharmaceutical Plant Science by "Big Data" of Long-time Investigation. World Journal of Pharmaceutical Research. 2020 Nov; 9(15): 72-82.

[14] Liao BH. Links between Species Pair's Co-dominance Abundance Dominancy of (Cremastra Appendiculata) of Biomedical and Pharmaceutical Plant and Elevations. European Journal of Biomedical and Pharmaceutical sciences. 2020 Nov; 7(12): 54-59.

[15] Liao BH. Relation between plant average height of (Cremastra appendiculata) and elevations. GSC Advanced Research and Reviews. 2020 Nov; 5(2): 104-10.

[16] Liao BH. Links between Biomass of (Cremastra appendiculata) Roots Cuticle and Elevation along Elevation Gradient by Big Data of long-time wild investigation in Mei County. International Journal of Applied Science. 2020 Nov; 3(11): 1-7.

[17] Liao BH. Links between Biomass of (Cremastra Appendiculata) Roots Cuticle and Daily Solar Radiation by Big Data of Long-Time Wild Investigation in Mei County. EAS Journal of Pharmacy and Pharmacology. 2020 Dec; 2 (6): 205-10.

[18] Liao BH. Links between Leafstalk Biomass of (Cremastra appendiculata) and Elevation by Big Data of Long-time Wild Investigation in Mei-County. Journal of Drug Delivery and Therapeutics. 2020 Dec; 10(6): 55-60. 
[19] Liao BH. Links between Biomass of (Cremastra Appendiculata) Stems Cuticle and Elevation by Big Data of Longtime Wild Investigation in Mei County. Sumerianz Journal of Agriculture and Veterinary.2020Dec; 3(12):178-82.

[20] Liao BH. Links between Important Values of (Cremastra appendiculata) and elevations by long-time investigation and qualitative analysis and quantitative statistics of "Big data". International Journal of Science and Research Archive. 2020 Dec; 1(2): 44-50.

[21] Liao BH. Links between Moisture Content of Biomass of (Cremastra Appendiculata) and Elevation by Long-time Investigation and Qualitative Analysis and Quantitives Statistics of "Big Data". January of Biological Innovative. 2021 Jan; 10(1): 208-16.

[22] Burin G, Jr PR, Quental TB. Macroevolutionary stability predicts interaction patterns of species in seed dispersal networks. Science. 2021 May; 372(6543): 733-37.

[23] Izuishi Y, Isaka N, Li H, Nakanishi K, Kageyama J, Ishikawa K, Shimada T, Masuta C, Yoshikawa N, Kusano H, Yazaki K. Apple latent spherical virus (ALSV)-induced gene silencing in a medicinal plant, Lithospermum erythrorhizon. Scientific Reports. 2020 Aug; 10(1): 13555.

[24] Gul R, Nisar A, Rab A, Ahmad N, Fazal H, Akbar F, Ullah I, Mukhtar S, Samad N. Photodependent somatic embryogenesis from non-embryogenic calli and its polyphenolics content in high-valued medicinal plant of Ajuga bracteosa. Journal of Photochemistry and Photobiology. B, Biology. 2019 Jan; 190(1): 59-65.

[25] Das A, Kamal S, Shakil NA, Sherameti I, Oelmüller R, Dua M, Tuteja N, Johri AK, Varma A. The root endophyte fungus Piriformospora indica leads to early flowering, higher biomass and altered secondary metabolites of the medicinal plant, Coleus forskohlii. Plant Signaling \& Behavior. 2012 Jan; 7(1): 103-12.

[26] Lombardo U, Iriarte J, Hilbert L, Ruiz-Pérez J, Capriles JM, Veit H. Early Holocene crop cultivation and landscape modification in Amazonia. Nature. 2020 May; 581(7807): 190-93.

[27] Singh SP, Gaur R. Evaluation of antagonistic and plant growth promoting activities of chitinolytic endophytic actinomycetes associated with medicinal plants against Sclerotium rolfsii in chickpea. Journal of Applied Microbiology. 2016 Aug; 121(2): 506-18.

[28] Laura H. Biodiversity: saving Florida panther makes sense. Nature. 2005 Nov; 438(7065): 156.

[29] Larsen HO. Commercial medicinal plant extraction in the hills of Nepal: local management system and ecological sustainability. Environmental Management. 2002 Jan; 29(1): 88-101.

[30] Huma A, Khan MA, Kayani WK, Dilshad E, Rani R, Khan RS. Production of biomass and medicinal metabolites through adventitious roots in Ajuga bracteosa under different spectral lights. Journal of Photochemistry and Photobiology. B, biology. 2019 Apr; 193: 109-17.

[31] Renner SC. Biodiversity: there's a role to be played by 'museum-keepers' too. Nature. 2005 Dec; $438(7070): 914$.

[32] Das K, Dang R, Shivananda TN, Sur P. Interaction between phosphorus and zinc on the biomass yield and yield attributes of the medicinal plant stevia (Stevia rebaudiana). Scientific World Journal. 2005 May; 5(1): 390-95.

[33] Cotto O, Wessely J, Georges D, Klonner G, Schmid M, Dullinger S, Thuiller W, Guillaume F. A dynamic ecoevolutionary model predicts show response of alpine plants to climate warming. Nature Communications. 2017 May; 8(1): 15399.

[34] Opgenoorth L, Hotes S, Mooney H. IPEPS: Biodiversity panel should play by rules. Nature. 2014 Feb; 506(7487): 159.

[35] Clark JS, McLachlan JS. Stability of forest biodiversity. Nature. 2003 Jun; 423(6940): 635-38.

[36] Song H, Payne S, Gray M, You LC. Spatiotemporal modulation of biodiversity in a synthetic chemical- mediated ecosystem. Nature Chemical Biology. 2009 Dec; 5(12): 929-35.

[37] Waldron A, Miller DC, Redding D, Mooers A, Kuhn TS, Nibbelink N, Roberts JT, Tobias JA, Gittleman JL. Reductions in global biodiversity loss predicted rom conservation spending. Nature. 2017 Nov; 551(7689): 530.

[38] Elkins AC, Deseo MA, Rochfort S, Ezernieks V, Spangenberg G. Development of a validated method for the qualitative and quantitative analysis of cannabinoids in plant biomass and medicinal cannabis resin extracts obtained by super-critical fluid extraction. Journal of Chromatography B. Analytical Technologies in the Biomedical and Life Sciences. 2019 Mar; 1109(1): 76-83.

[39] Kenneth GC, Patricio G. A global perspective on sustainable intensification research. Nature Sustainability. 2020 Apr; 3(4): 262-68. 
[40] Grass I, Kubitza C, Krishna VV, Corre MD, Mußhoff O, Pütz P, Drescher J, Rembold K, Ariyanti ES, Barnes AD, Brinkmann N, Brose U, Brümmer B, Buchori D, Daniel R, Darras KFA, Faust H, Fehrmann L, Hein J, Hennings N, Hidayat P, Hölscher D, Jochum M, Knohl A, Kotowska MM, Krashevska V, Kreft H, Leuschner C, Lobite NJS, Panjaitan R, Polle A, Potapov AM, Purnama E, Qaim M, Röll A, Scheu S, Schneider D, Tjoa A, Tscharntke T, Veldkamp E, Wollni M. Trade-offs between multifunctionality and profit in tropical small-hoder landscapes. Nature Communications. 2020 Mar; 11(1): 1186.

[41] Harris J, Kotiaho JS. New jargon seeping slowly into biodiversity world. Nature. 2018 Oct; 562(7725): 39.

[42] Kumar V, Roy BK. Population authentication of the traditional medicinal plant Cassiatora L. based on ISSR markers and FTIR analysis. Scientific Reports. 2018 Jun; 8(1): 10714.

[43] Jacquelie O, Bernhard S, Schaepman-Strub G, Niklaus PA. Terrestrial land-cover type richness is positively linked to landscape level functioning. Nature Communications. 2020 Jan; 11(1): 154.

[44] Liao AU, Georgina MM, Ekins P. Limits to agricultural land for retaining acceptable levels of local biodiversity. Nature Sustainability. 2019 Jun; 2(6): 491-98.

[45] Liao B, Ying ZX, Hiebeler DE, Wang YQ, Takada T, Nijs I. Species extinction thresholds in the face of spatially correlated periodic disturbance. Scientific Reports. 2015 Oct; 5(1): 15455.

[46] Liao B, Chen JH, Ying ZX, Hiebeler DE, Nijs I. An extended patch-dynamic framework for food chains in fragmented landscapes. Scientific Reports. 2016 Sep; 6(1): 33100.

[47] Liao B, Boeck, HJD., Li ZQ, Nijs I. Gap formation following climatic events in spatially structured plant communities. Scientific Reports. 2015 Jun; 5(1): 11721.

[48] Liao B, Bogaert J, Nijs I. Species interactions determine the spatial mortality patterns emerging in plant communities after extreme events. Scientific Reports. 2015 Jun; 5(1): 11229.

[49] Zhu DM, Liao BH. A dynamical system of human cognitive linguistic theory in learning and teaching of the typical university in Henan Province. International Journal of Pharmacy \& Therapeutics. 2015 Jan; 6(1): 4-6.

[50] Jin D, Dai KP, Xie Z, Chen J. Secondary Metabolites Profiled in Cannabis Inflorescences, Leaves, Stem Barks, and Roots for Medicinal Purposes. Scientific Reports. 2020 Feb; 10(1): 3309.

[51] Yang Y, Sun M, Chen Q, Teixeira da Silva JA, Wang A, Yu X, Wang L.. Germplasm resources and genetic breeding of Paeonia: a systematic review. Horticulture Research. 2020 Jul; 7(1): 107.

[52] Joseph PN. Synthetic metabolism goes green. Nature. 2010 Nov; 468(7322): 380-81.

[53] Ibisch PL, Jennings MD, Kreft S. Biodiversity needs the help of global change managers, not museum-keepers. Nature. 2005 Nov; 438(7065):156.

[54] Saeed S, Ali H, Khan T, Kayani W, Khan MA. Impacts of methyl jasmonate and phenyl acetic acid on biomass accumul -ation and antioxidant potential in adventitious roots of Ajuga bracteosa Wall ex Benth., a high valued endangered medicinal plant. Physiology and Molecular Biology of Plants. 2017 Jan; 23(1): 229-37.

[55] Martina K, Sabine E, Etemadi M, White 3rd RA, El-Arabi TF, Berg G. Deciphering the microbiome shift during fermentation of medicinal plants. Scientific Reports. 2019 Sep; 9(1): 13461.

[56] Schultz F, Anywar G, Tang HQ, Chassagne F, Lyles JT, Garbe LA, Quave CL. Targeting ESKAPE pathogens with antiinfective medicinal plants from the Greater Mpigi region in Uganda. Scientific Reports. 2020 Jul; 10 (1): 11935.

[57] MacDougall AS, McCann KS, Gellner G, R Turkington R. Diversity loss with persistent human disturbance increases vulnerability to ecosystem collapse. Nature. 2013 Feb; 494(7435): 86-89.

[58] Lyubchyk S, Shapovalova O, Lygina O, Oliveira MC, Appazov N, Lyubchyk A, Charmier AJ, Lyubchik S, Pombeiro AKL. Integrated Green Chemical Approach to the Medicinal Plant Carpobrotus edulis Processing. Scientific Reports. 2019 Dec; 9(1): 19171.

[59] Mohanraj K, Karthikeyan BS, Vivek-Ananth RP, Chand RPB, Aparna SR, Mangalapandi P, Samal A. IMPPAT: A curated database of Indian Medicinal Plants, Phytochemistry And Therapeutics. Scientific Reports. 2020 Mar; 8(1): 4329. 